\title{
DEVELOPMENT OF HIGH STRENGTH SELF-COMPACTED SELF-CURING CONCRETE WITH MINERAL ADMIXTURES
}

\author{
Selvamony C. ${ }^{1}$, Ravikumar M.S. ${ }^{2}$, Kannan S.U. ${ }^{3}$, Basil Gnanappa S. ${ }^{4}$ \\ ${ }^{1,2,3}$ Research Scholars, Sathyabama University, Chennai, India \\ ${ }^{4}$ Gnanadhasan Polytechnic, Nagercoil ,India \\ Email: 'selvamony•2007@yahoo.com
}

\begin{abstract}
Conventional concrete is the most widely used construction material throughout the world because of its versality, mouldability, durability, and resistance to fire and energy efficiency. However, its major disadvantages like poor tensile strength, limited ductility and little resistance to cracking resists its use as a structural material. Hence, in order to overcome these difficulties several new materials have been developed in the recent past. Admixtures are ingredients other than water, aggregates, hydraulic cement and fibers that are added to the concrete batch immediately before or during mixing. Mineral admixtures are usually added to concrete in larger amounts to enhance the workability of fresh concrete; to improve resistance of concrete to thermal cracking, alkali-aggregate expansion and sulphate attack and to enable a reduction in cement content. The objective of this study is to evaluate the effectiveness of various percentages of mineral admixtures in producing SCC. In this study, the effect of replacing the cement, coarse aggregate and fine aggregate by limestone powder (LP) with silica fume, quarry dust and clinkers respectively and their combinations of various proportions on the properties of SCC has been compared. The use of SF in Concrete signio cantly increased the dosage of superplasticiser (SP). At the same constant SP dosage $(08 \%)$ and mineral additives content (30\%), LP can better improve the workability than that of control and fine aggregate mixtures by $(5 \%$ to $45 \%$ ). However, the results of this study suggest that certain QD, SF and LP combinations can improve the workability of SCCs, more than QD, SF and LP alone.
\end{abstract}

Keywords: Self-compacting Concrete; limestone powder; Silica Fume; Quarry Dust; Clinkers

\section{INTRODUCTION}

Self-Compacting Concrete (SCC) is the concrete that can be compacted into every corner of the formwork by means of its self-weight only. SCC was developed by Professor Okamura in 1986 for the first time in the world and has been spread to all over the world as the original of Japan. Self-compacting concrete (SCC) is an innovative concrete that does not require vibration for placing and compaction. It is able to flow under its own weight, completely filling formwork and achieving full compaction, even in the presence of congested reinforcement. The hardened concrete is dense, homogeneous and has the same engineering properties and durability as traditional vibrated concrete. Self-compacting concrete (SCC) is a mean to create uniformity in the quality of concrete by controlling the ever present problem of insufficient compaction by a workforce that was losing skilled labour and by the increased complexity of designs and reinforcement details in modern structural members. Durability was the main concern and the purpose was to develop a concrete mix that would reduce or eliminate the need for vibration to achieve consolidation. Self compacting concrete achieves this by its unique fresh state properties. In the plastic state, it flows under its own weight and maintain homogeneity while completely filling any formwork and passing around congested reinforcement. In the hardened state, it equals or excels standard concrete with respect to strength and durability. Although self-compacting concrete has been successfully used in Japan and European there has been some reluctance to employ it in India and as a consequence it has suffered very little development with local materials.

Therefore, it is essential to have proper mix design. Self-compacting concrete offers a rapid rate of concrete placement, with faster construction times and ease of flow around congested reinforcement. The fluidity and segregation resistance of SCC ensures a high level of homogeneity, minimal concrete voids and uniform concrete strength, providing the potential for a superior level of finish and durability to the structure. SCC is often produced with low water-cement ratio providing the potential for high early strength, earlier demoulding and faster use of elements and structures. The elimination of vibrating equipment improves the environment on and near construction and precast sites where concrete is being placed, reducing the exposure of workers to noise and vibration. The improved construction practice and performance, combined with the health and safety benefits, make SCC a very attractive solution for both precast concrete and civil engineering construction.

The durability of a concrete repair can depend on many factors. Those most often considered are cement reactivity with environment, low permeability, diffusion coefocient of species such as sulfate ions and 
compressive strength. The water absorption is also very important factor effecting durability such as freezing and thawing. The use of mineral additives may provide a way of improving the durability of SCC depending on the type and amount of mineral additive used. In addition, in the absence of self-compactability the success of mortars depends on the compaction degree supplied at application site.

For improving strength and durability properties; limestone powders produce a more compact structure by pore-olling effect. In the case of SF and FA, it also reacts with cement by binding $\mathrm{Ca}(\mathrm{OH}) 2$ with free silica by a pozzolanic reaction forming a non-soluble $\mathrm{CSH}$ structure (O'Flaherty \& Mangat 1999). The main objective of the present study is to investigate a suitable combination of LP, QD ,SF and Clinkers that would improve the properties of the SCCs more than when these materials would be used separately.

\section{SELF-COMPACTING CONCRETE}

\section{A. Definition}

The concrete that is capable of self-consolidation and occupying all the spaces in the formwork without any vibration is termed as Self-Compacting Concrete. The guiding principle behind the self-compaction is that "the sedimentation velocity of a particle is inversely proportional to the viscosity of the floating medium in which the particle exists".

\section{B. Ingredients of SCC}

The constituent material used for the production of SCC are discussed as follows:

1) Cement: Ordinary Portland Cement (53 grade) Dalmia cement conforming to IS 8112 was used. The different laboratory tests were conducted on cement to determine standard consistency, initial and final setting time, and compressive strength as per IS 4031 and IS 269-1967. The results are tabulated in Table.1. The results conforms to the IS recommendations.

Table.1. Results

\begin{tabular}{|l|l|l|}
\hline SI.No & Test Conducted & Result \\
\hline 1 & Standard consistency & $32 \%$ \\
\hline 2 & Initial Setting Time & 150 minutes \\
\hline 3 & Final setting time & 330 minutes \\
\hline 4 & 3 day compressive strength & $27.67 \mathrm{~N} / \mathrm{nm}^{2}$ \\
\hline 5 & 7 day compressive strength & $39.93 \mathrm{~N} / \mathrm{nm}^{2}$ \\
\hline 6 & 28 day compressive strength & $54.60 \mathrm{~N} / \mathrm{nm}^{2}$ \\
\hline
\end{tabular}

2) Fine: Aggregates: Natural sands, crushed and rounded sands, and manufactured sands are suitable for SCC. River sand of specific gravity 2.58 and conforming to zone II of IS 363 was used for the present study. The particle size distribution is given in Table. 2 .

Table 2. Fine aggregate Particle Size Distribution

\begin{tabular}{|l|l|l|l|}
\hline $\begin{array}{l}\text { Passing } \\
\text { through IS } \\
\text { sieve }(\mathrm{mm})\end{array}$ & $\begin{array}{l}\text { Retained } \\
\text { on IS sieve } \\
(\mathrm{mm})\end{array}$ & $\begin{array}{l}\text { Cumulative \% } \\
\text { retained }\end{array}$ & $\begin{array}{c}\% \\
\text { Passing }\end{array}$ \\
\hline 4.75 & 2.36 & 2.00 & 98.00 \\
\hline 2.36 & 1.18 & 21.20 & 78.88 \\
\hline 1.18 & 0.6 & 46.40 & 53.60 \\
\hline 0.6 & 0.3 & 63.14 & 36.68 \\
\hline 0.3 & 0.15 & 88.14 & 11.86 \\
\hline
\end{tabular}

Fineness modulus $=3.06$

Dry rodded Bulk density $=1.84 \mathrm{~g} / \mathrm{cc}$

3) Coarse Aggregate: The shape and particle size distribution of the aggregate is very important as it affects the packing and voids content. The moisture content, water absorption, grading and variations in fines content of all aggregates should be closely and continuously monitored and must be taken into account in order to produce SCC of constant quality. Coarse aggregate used in this study had a maximum size of $20 \mathrm{~mm}$. Specific gravity of coarse aggregate used was 2.8. The particle size distribution is given in Table. 3 .

Table 3. Coarse aggregate Particle Size Distribution

\begin{tabular}{|l|l|l|l|}
\hline $\begin{array}{l}\text { Passing } \\
\text { through IS } \\
\text { sieve }(\mathrm{mm})\end{array}$ & $\begin{array}{l}\text { Retained } \\
\text { on IS sieve } \\
(\mathrm{mm})\end{array}$ & $\begin{array}{l}\text { Cumulative \% } \\
\text { retained }\end{array}$ & $\begin{array}{c}\% \\
\text { Passing }\end{array}$ \\
\hline 20 & 12.5 & 100 & 100 \\
\hline 12.5 & 10 & 7.5 & 92.5 \\
\hline 10 & 4.75 & $30 . .1$ & 69.99 \\
\hline 4.75 & Pan & 90.45 & 9.55 \\
\hline
\end{tabular}

Fineness modulus $=7.3$

Dry rodded Bulk density $=1.66 \mathrm{~g} / \mathrm{cc}$

4) Water: Ordinary potable water available in the laboratory was used.

5) Chemical Admixtures: Superplasticisers or high range water reducing admixtures are an essential component of SCC. Conplast SP 430 was used as superplasticiser and Structuro 485 was used as viscosity modifying agent and Concure was used as self curing admixture

6) Lime stone powder: A high quality lime stone powder generally permits a reduction in water content of a concrete mixture, without loss of workability. 
Lime stone powder obtained from India's cement Limited, Tirunelveli was used for the study. The chemical composition of lime stone powder is given in Table 4.

Table 4. Chemical composition of Lime stone powder

\begin{tabular}{|l|l|l|l|}
\hline $\begin{array}{l}\text { Passing } \\
\text { through IS } \\
\text { sieve }(\mathrm{mm})\end{array}$ & $\begin{array}{l}\text { Retained } \\
\text { on IS sieve } \\
(\mathrm{mm})\end{array}$ & $\begin{array}{l}\text { Cumulative \% } \\
\text { retained }\end{array}$ & $\begin{array}{c}\% \\
\text { Passing }\end{array}$ \\
\hline 20 & 12.5 & 100 & 100 \\
\hline 12.5 & 10 & 7.5 & 92.5 \\
\hline 10 & 4.75 & $30 . .1$ & 69.99 \\
\hline 4.75 & Pan & 90.45 & 9.55 \\
\hline
\end{tabular}

7) Rock dust: The granite fines obtained as by-product in the production of concrete aggregates are referred as quarry or rock dust [4]. Rock dust of specific gravity 2.37 passing through 150-micrometer sieve was used in this study. The chemical composition of rock dust is given in Table 5.

Table 5. Chemical composition of Rock dust

\begin{tabular}{|l|l|l|}
\hline SI.No & Constituents & Quantity $(\%)$ \\
\hline 1 & Silica $\left(\mathrm{SIO}_{2}\right)$ & 70.74 \\
\hline 2 & Aluminum Dioxide $\left(\mathrm{Ai}_{2} \mathrm{O}_{3}\right)$ & 20.67 \\
\hline 3 & Ferric Oxide $\left(\mathrm{Fe}_{2} \mathrm{O}_{3}\right)$ & 2.88 \\
\hline 4 & Titanium Dioxide $\left(\mathrm{TiO}_{2}\right)$ & 0.33 \\
\hline 5 & Sodium Oxide $\left(\mathrm{Na}_{2} \mathrm{O}\right)$ & 0.11 \\
\hline 6 & Potassium Oxide $\left(\mathrm{K}_{2} \mathrm{O}\right)$ & 0.19 \\
\hline 7 & Magnesium Oxide $(\mathrm{MgO})$ & 1.57 \\
\hline 8 & Manganese Dioxide $\left(\mathrm{MnO}_{2}\right)$ & 0.01 \\
\hline 9 & Calcium Oxide $(\mathrm{CaO})$ & 0.2 \\
\hline 10 & (Zinc Oxide $(\mathrm{ZnO})$ & 0.01 \\
\hline 11 & Lead $(\mathrm{Pb})$ & $625 \mathrm{ppm}$ \\
\hline 12 & Chromium $(\mathrm{Cr})$ & $125 \mathrm{ppm}$ \\
\hline 13 & Loss on Ignition $(\mathrm{LOI})$ & 0.72 \\
\hline
\end{tabular}

8) Silica fume: Silica fume imparts very good improvement to rheological, mechanical and chemical properties. It improves the durability of the concrete by reinforcing the microstructure through filler effect and thus reduces segregation and bleeding. It also helps in achieving high early strength. Silica fume of specific gravity 2.34 was used in this study. The chemical composition of Silica fume is given in Table 6 .

\section{EXPERIMENTAL INVESTIGATION}

Tests on fresh concrete were performed to study the workability of SCC with various proportions of rock dust and silica fume. The tests conducted are listed below: i) Slump flow test

ii) V-funnel flow test

iii) Orimet test

iv) U-tube test

v) J-Ring test

vi) L-box test

Table 6. Chemical composition of Silica fume

\begin{tabular}{|l|l|l|}
\hline SI.No & Constituents & Quantity (\%) \\
\hline 1 & Silica $\left(\mathrm{SIO}_{2}\right)$ & 91.03 \\
\hline 2 & Aluminum Dioxide $\left(\mathrm{Ai}_{2} \mathrm{O}_{3}\right)$ & 0.39 \\
\hline 3 & Ferric Oxide $\left(\mathrm{Fe}_{2} \mathrm{O}_{3}\right)$ & 2.11 \\
\hline 4 & Calcium Oxide $(\mathrm{CaO})$ & 1.5 \\
\hline 5 & Loss on Ignition $(\mathrm{LOI})$ & 4.05 \\
\hline
\end{tabular}

The acceptance criteria for the fresh properties of SCC are listed in Table. 7. Tests on hardened concrete were also conducted for mixes with various proportions of rock dust. An investigation for the optimum percentage of replacement of cement with rock dust was performed.

Table 7. Acceptance Criteria for SCC

\begin{tabular}{|l|l|l|l|l|}
\hline SI.No & & \multirow{2}{*}{ Method } & \multicolumn{2}{|c|}{ Uypical range of values } \\
\cline { 4 - 5 } & & & Minimum & Maximum \\
\hline 1 & Slump-flow & Mm & 650 & 800 \\
\hline 2 & T50 slump flow & $\mathrm{sec}$ & 2 & 5 \\
\hline 3 & J-ring & $\mathrm{mm}$ & 0 & 10 \\
\hline 4 & V-funner & $\mathrm{sec}$ & 6 & 12 \\
\hline 5 & V-Funnel at $T_{5}$ minutes & $\mathrm{sec}$ & 0 & +3 \\
\hline 6 & L-Box & $\left(\mathrm{h}_{2} / \mathrm{h}_{1}\right)$ & 0.8 & 1.0 \\
\hline 7 & U-Box & $\left(\mathrm{h}_{2} / \mathrm{h}_{1}\right)$ & 0 & 30 \\
\hline 8 & Fill Box & $\%$ & 90 & 100 \\
\hline 9 & GTM Screen stability test & $\%$ & 0 & 15 \\
\hline 10 & Orimet & $\mathrm{sec}$ & 0 & 15 \\
\hline
\end{tabular}

Mix proportion of SCC

There is no standard method for SCC mix design and many academic institutions, admixture, ready-mixed, pre cast and contracting companies have developed their own mix proportioning methods.

Okamura's method, based on EFNARC specifications, was adopted for mixed design. Different mixes were prepared by varying the amount of coarse aggregate, fine aggregate, water powder ratio, super plasticisers and VMA. After several trials, SCC mix satisfying the test criteria was obtained. The details of the design mix are given in Table 8. 
Table 8. Mix Proportion for SCC

\begin{tabular}{|l|l|}
\hline Particulars & $\begin{array}{l}\text { Quantity } \\
\left(\mathrm{Kg} / \mathrm{m}^{3}\right)\end{array}$ \\
\hline Cement & 531.05 \\
\hline Fine aggregate & 702.61 \\
\hline Coarse aggregate & 360.67 \\
\hline Super plasticizer $\left(\mathrm{lt} / \mathrm{m}^{3}\right)$ & 13.42 \\
\hline $\begin{array}{l}\text { Viscosity Modifying agent } \\
\left(1 \mathrm{t} / \mathrm{m}^{3}\right)\end{array}$ & 4 \\
\hline
\end{tabular}

\section{RESULTS AND DISCUSSION}

Test result on the effect of silica fume with lime stone powder as a mineral admixture in the fresh and hardened properties of SCC by replacing 2.00 to $14.00 \%$ of cement, quarry dust by 5.00 to $45.00 \%$ of fine aggregates, Clinkers 2.00 to $20.00 \%$ of coarse aggregates in various proportions and superplasticizer with Viscosity Modifying Agent by adding $0.8 \%$ of water are discussed in following tables.
Six standard cubes each for various percentages were tested to determine the 7- day, 21- day and 28- day compressive strength and results are given in Table 10. Figure.1(a-d) below shows the variation of cube compressive strength with various replacements of admixtures. It was found that the 7-day, 21- day and 28day cube compressive strength increased with increase in various percentages of admixtures. More than $8 \%$ replacement of cement by lime stone powder with silica fume showed very significant reduction in the compressive strength. Three cylinder samples were cast with different percentages of rock dust with clinkers and tested to determine the 28-day cylinder compressive strength. The 28-day cylinder compressive strength decreased for all the mixes with increase in content of limestone powder with silica fume. Split tensile strength also decreased as the percentage replacement of cement with limestone powder increased and results are given in Table 10.

Table 9. Test Result on Fresh Concrete

\begin{tabular}{|l|c|c|c|c|c|c|c|c|c|c|}
\hline \multirow{2}{*}{ Identification } & \multicolumn{3}{|c|}{ Replacement details \% } & \multicolumn{6}{c|}{ Tests on fresh concrete } \\
\cline { 2 - 11 } & LP & SF & QD & CL & Orimet & $\begin{array}{c}\text { L } \\
\text { Box }\end{array}$ & $\begin{array}{c}\text { V } \\
\text { Funnel }\end{array}$ & $\begin{array}{c}\text { Slump } \\
\text { Flow }\end{array}$ & $\begin{array}{c}\text { U } \\
\text { Box }\end{array}$ & $\begin{array}{c}\text { J } \\
\text { Ring }\end{array}$ \\
\hline SCC 1 & 2.00 & 1.00 & 5.00 & 2.00 & 4.7 & 0.80 & 7.2 & 650 & 30 & 10 \\
\hline SCC 2 & 2.00 & 2.00 & 10.0 & 4.00 & 4.3 & 0.82 & 7.4 & 656 & 26 & 9.8 \\
\hline SCC 3 & 3.00 & 3.00 & 15.0 & 6.00 & 4.1 & 0.82 & 7.5 & 658 & 24 & 9.6 \\
\hline SCC 4 & 4.00 & 4.00 & 20.0 & 8.00 & 3.9 & 0.84 & 7.5 & 664 & 21 & 9.5 \\
\hline SCC 5 & 5.00 & 5.00 & 25.0 & 10.0 & 3.8 & 0.85 & 7.7 & 668 & 20 & 9.3 \\
\hline SCC 6 & 6.00 & 6.00 & 25.0 & 12.0 & 3.6 & 0.87 & 7.8 & 672 & 18 & 9.1 \\
\hline SCC 7 & 7.00 & 1.00 & 30.0 & 14.0 & 3.1 & 0.88 & 7.9 & 675 & 16 & 9.0 \\
\hline SCC 8 & 8.00 & 2.00 & 35.0 & 16.0 & 3.1 & 0.88 & 8.1 & 682 & 15 & 8.8 \\
\hline SCC 9 & 9.00 & 3.00 & 40.0 & 18.0 & 2.9 & 0.92 & 8.3 & 688 & 12 & 8.5 \\
\hline SCC 10 & 10.0 & 4.00 & 45.0 & 20.0 & 2.8 & 0.94 & 8.4 & 696 & 10 & 8.4 \\
\hline
\end{tabular}


Table 10. Test Result on Hardened Concrete

\begin{tabular}{|c|c|c|c|c|c|c|}
\hline \multirow{2}{*}{ Identification } & \multicolumn{2}{|c|}{ Cube Strength $\left(\mathrm{N} / \mathrm{mm}^{2}\right)$} & \multicolumn{3}{c|}{$\begin{array}{c}\text { Cylinder Test } \\
\left(\mathrm{N} / \mathrm{mm}^{2}\right)\end{array}$} \\
\cline { 2 - 7 } & $\begin{array}{c}7 \\
\text { Days }\end{array}$ & $\begin{array}{c}21 \\
\text { Days }\end{array}$ & $\begin{array}{c}28 \\
\text { Days }\end{array}$ & $\begin{array}{c}7 \\
\text { Days }\end{array}$ & $\begin{array}{c}21 \\
\text { Days }\end{array}$ & $\begin{array}{c}28 \\
\text { Days }\end{array}$ \\
\hline SCC 1 & 20.5 & 28.8 & 40.7 & 2.4 & 3.5 & 4.3 \\
\hline SCC 2 & 20.7 & 29.6 & 41.6 & 2.6 & 3.75 & 4.5 \\
\hline SCC 3 & 22.6 & 29.8 & 42.3 & 2.7 & 3.82 & 4.6 \\
\hline SCC 4 & 22.7 & 30.8 & 42.5 & 2.9 & 3.9 & 4.68 \\
\hline SCC 5 & 23.0 & 31.8 & 42.6 & 3.1 & 3.94 & 4.74 \\
\hline SCC 6 & 23.4 & 33.2 & 43.7 & 3.3 & 4.1 & 4.81 \\
\hline SCC 7 & 24.0 & 34.7 & 45.0 & 3.4 & 4.2 & 4.92 \\
\hline SCC 8 & 23.8 & 34.5 & 44.7 & 3.1 & 4.0 & 4.72 \\
\hline SCC 9 & 23.6 & 34.1 & 44.3 & 3.0 & 3.7 & 4.61 \\
\hline SCC 10 & 23.1 & 34.0 & 44.0 & 2.8 & 3.5 & 4.58 \\
\hline
\end{tabular}

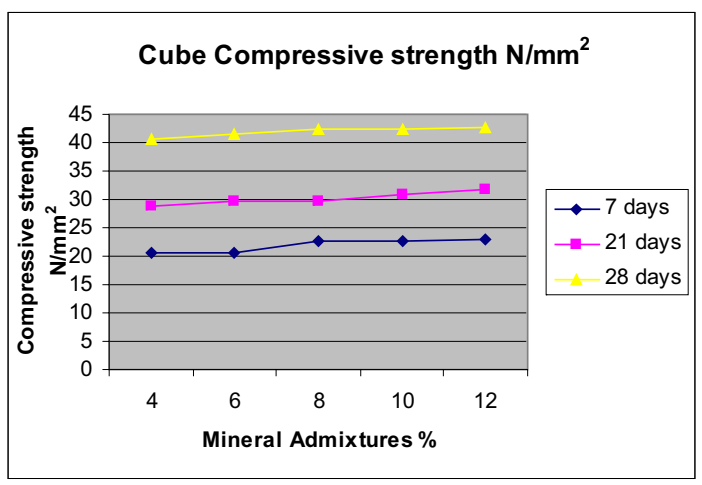

(a)

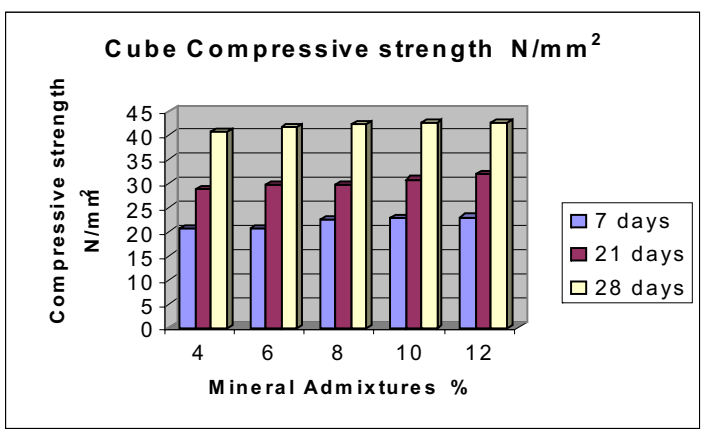

(b)

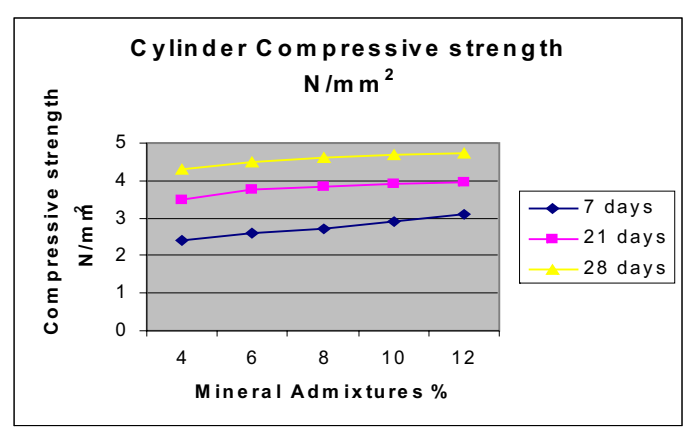

(c)

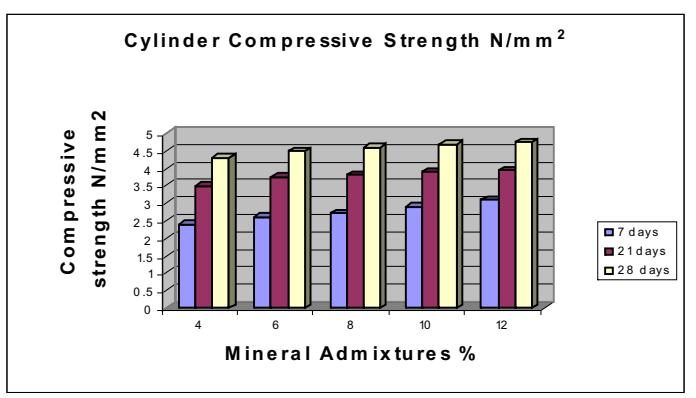

(d)

Fig.1.(a,b,c \& d) Cube/Cylinder Compressive Strength of SCC with various admixtures

\section{CONCLUSION}

From the experimental investigation, it was observed that both admixtures affected the workability of SCC adversely. A maximum of $8 \%$ of lime stone powder with silica fume, $30 \%$ of quarry dust and $14 \%$ of clinkers was able to be used as a mineral admixture without affecting the self-compactability. Silica fume was observed to improve the mechanical properties of SCC, while lime stone powder along with quarry dust affected mechanical properties of SCC adversely.

\section{REFERENCES}

[1] Nan su, Kung-chung hsu, His-wen chai, 2001, "A simple mix design method for Self compacting concrete", Cement and Concrete Research, Vol.31, pp.1799-1809.

[2] Sahmaran, Christianto,Yaman, 2006, "The effect of chemical admixtures and mineral additives on the properties of self-compacting mortars", Cement and Concrete Composites, Vol 28, pp.432-440. 
[3] EFNARC, 2002, "Specification and Guidelines for Self-Compacting concrete". EFNARC(European Federation of Producers and Applicators of Specialist Products for Structures). http://www.efnarc.org/pdf/SandGforSCC.PDF

[4] D.W.S Ho, A.M.M Shenin, C.C Ng, C.T Tam, 2002, "The use of quarry dust for SCC Applications", Cement and Concrete research, Vol.32, pp.505-511.

[5] N.Ganesan,P.V.Indira, P.T. Santhosh kumar, 2006,

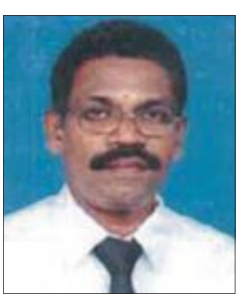

Selvamony is a research scholar in Sathyabama University and an Assistant Professor at Sun College of Engineering \& Technology, Nagercoil. He graduated in Civil Engineering from Manonmaniam Sundaranar University and a Post graduate in Structural Engineering in Sathyabama University. His area of research is "Analysis \& Design of seismic resistant structures". "Durability Aspects of Steel Fibre-Reinforced SCC", Indian Concrete Journal, pp.31-37. 